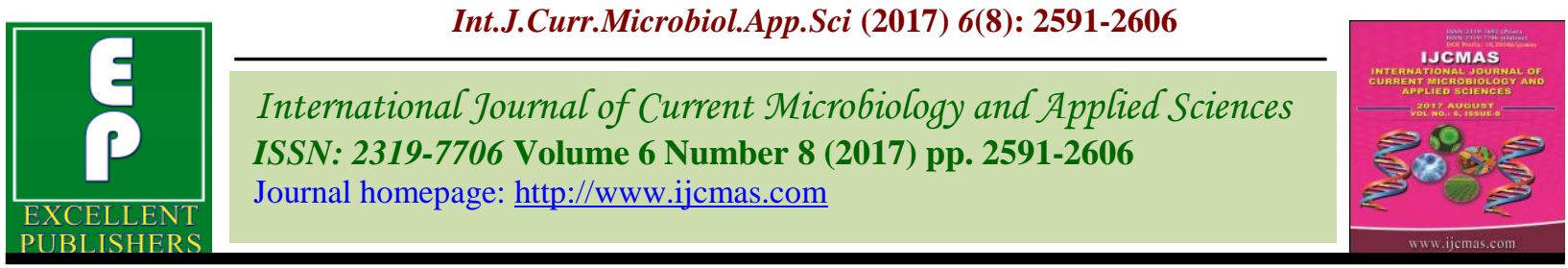

Review Article

https://doi.org/10.20546/ijcmas.2017.608.308

\title{
Significant Role of Ornamental Plants as Air Purifiers - A Review
}

\author{
V.S. Reshma ${ }^{1}$, Prashant Kumar ${ }^{2}$ and G.S. Chaitra ${ }^{1}$ \\ ${ }^{1}$ Department of Horticulture, Lalbagh, Bengaluru-560004, Karnataka, India \\ ${ }^{2}$ Department of Fruits and Orchard Management, Faculty of Horticulture, Bidhan \\ Chandra Krishi Viswavidyalaya, Mohanpur, Nadi, West Bengal, India \\ *Corresponding author
}

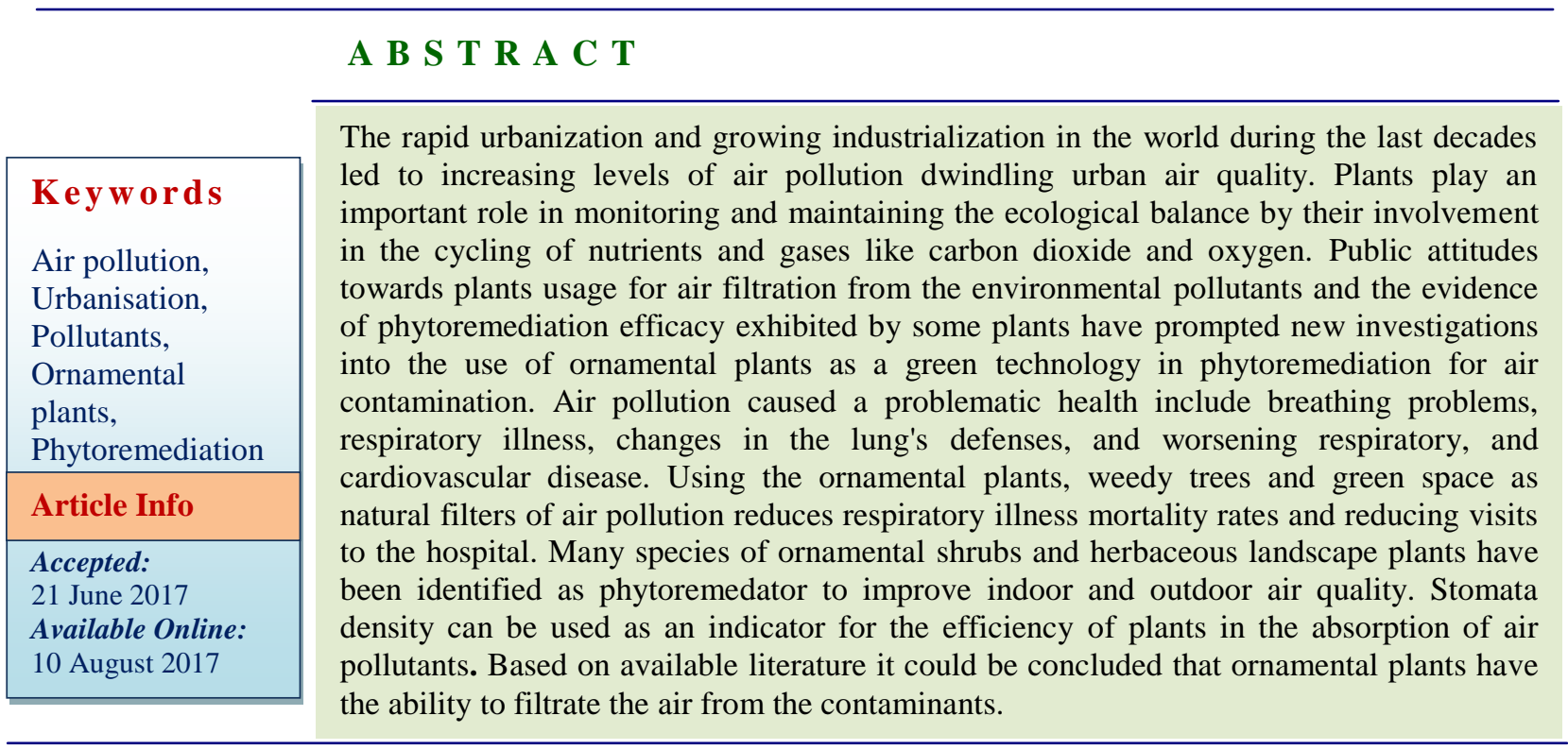

\section{Introduction}

Generally, plants have been labelled as the "lungs of cities" (McPherson, 2005) because they have the ability to remove contaminants from the air that is breathed. Acting as natural filters and reducing air pollution, it has been shown that plants generate health benefits by reducing the mortality rate and reducing visits to the hospital (Powe and Willis, 2004). Air pollution has been becoming a necessary evil with rapid industrialization and urbanization around the world, after it results in kinds of human health problems, such as ophthalmic, respiratory and cardiovascular diseases (Yang and Liu 2011). Naturally everyone likes to breathe fresh, clean air. But the atmosphere, that invisible yet essential ocean of different gases called air, is as susceptible to pollution from human activities as are water and land environments (Barfield et al., 1992). According to the WHO report, about 10 to 15 $\%$ of the total population of India is suffering from common cold, bronchitis, asthma, hay fever etc. These diseases are no doubt airborne and spread the infection from several hundred kilometers under favourable atmospheric conditions. Dust and soot in the air contribute to between 20 and 200 deaths each day in America's biggest cities. Ill health 
from microscopic particulates with tiny specks smaller than the width of a human hair can lodge deep in the lungs and are associated with respiratory diseases, heart attacks and premature deaths. The new research indicates elderly people suffer the most harm. In the United States the Environmental Protection Agency (EPA) currently sets the maximum allowable concentration of microscopic particles at $150 \mu \mathrm{m} / \mathrm{m}^{3}$ of air. The air is being continuously polluted in urban areas through heavy traffic, industry, domestic fuel combustion, stone quarries, coalmines and various agricultural activities from the adjoining areas. These particulates are no doubt dangerous to human health and environment causing various diseases to plants and animals, damage to properties including our cultural heritage, national monuments, archives etc. Dust concentration varies from place to place and hour to hour, diurnally depending upon traffic, type of industry etc. The highest dust concentration tends to be in summer, reaching maximum during mid-day and late-afternoon. In some large cities where wind and temperature fall more steadily, the concentration of dust also reduces accordingly.

\section{Pollution}

Pollution is defined as 'an undesirable change in physical, chemical and biological characteristics of air, water and land that may be harmful to living organisms, living conditions and cultural assets. The pollution control board defined pollution as unfavourable alteration of our surrounding, largely as a byproduct of human activities (Agarwal and Sharma, 1980). The most necessary thing for the survival of all living beings on this earth is Air. On an average, a person needs atleast $30 \mathrm{lb}$ of air every day to live, but only about $3 \mathrm{lb}$ of water and $1.5 \mathrm{lb}$ of food (Kumar et al., 2013). A person can live about 5 weeks without food and about 5 days without water, but only 5 minutes without air.
(Nahed G. Abd ElAziz et al., 2015) Various types of activity, including agriculture, industry and transportation, produce a large amount of wastes and new types of pollutants in air (Setyorini et al., 2002).

Pollutants are the substances that contaminate air, water and or soil. The most potential toxic elements in the air are the non-radioactive As, $\mathrm{Cd}, \mathrm{Cu}, \mathrm{Hg}, \mathrm{Pb}$ and $\mathrm{Zn}$ and radioactive $\mathrm{Sr}, \mathrm{Cs}$ and $U$ (referred to here as toxic metals) (Deveci and Ekmekyapar, 2008). Also, nitrogen dioxide $\left(\mathrm{NO}_{2}\right)$, Carbon Monoxide (CO), and Hydrocarbons (HC) are considered the main emissions, and higher levels can often be the result of increased airport vehicular traffic (Yang and Liu, 2011) Pollutants are not necessarily born as pollutants. On the contrary, they may be resources applied in the wrong places. Incorrect uses, accidental releases and/or technical limits make them harmful to our environment (Zhai, 2011).

Primary pollutants are usually produced from a process, such as from volcanic eruptions, $\mathrm{CO}, \mathrm{SO}_{2}, \mathrm{NO}_{2}, \mathrm{~Pb}, \mathrm{Hg}, \mathrm{CFCs}$ and $\mathrm{NH}_{3}$. Secondary pollutants are not emitted directly, rather, they form in the air when primary pollutants react or interact such as ground level ozone. Most of sources of air pollution are related to human's activities as a result of the modern life style. The main pollution sources include chemicals, industries, automobiles, coal-fired power plants, nuclear waste disposal activity, plastic factories etc. Agriculture air pollution comes from spraying of pesticides and herbicides. Harmful effects of pollution have both acute and chronic effects on human health. Health effects range anywhere from minor irritation of eyes and upper respiratory systems, heart disease, lung cancer and death. Ozone depletion is the result of air pollution. The air pollution control is the process of reducing the release of pollutants from industries, wastes of chimneys, fossil-fuel (coal), thermal power 
plants etc. It is regulated by various environmental agencies that establish limits for the discharge of pollutants in to air (Singh, 2013). The control of emissions can be realized in the number of ways such as collection of pollutants, cooling, emission control in automobile engines (Sharma, 2014). The planting of ornamental plants for the control of pollution and improvement of environment is an effective way. The proper planning and planting scheme depends upon the type of pollution. Tolerants and dust absorbing trees and shrubs should be planted for bioremediation of environment. The aim of the present review is to provide insight into how ornamental plants can be effectively utilised in reducing the air pollution (Table 1).

\section{Method of air pollution control}

Process of cleaning the air in environment by using plants is termed as Phytoremediation. The word phytoremediation comes from the Greek word phyto, meaning "plant" and the Latin word remediare, meaning "to remedy". This word is generally used to describe any system where plants are introduced into an environment to remove contaminants from it (Chhotu, et al., 2009). Certain species of higher plants can accumulate very high concentrations of metals in their tissues without-showing toxicity (Klassen et al., 2000).

\section{Phytoremediation of air pollutants}

Air pollutants may be classified as anthropogenic and natural pollutants according to their sources, or primary and secondary pollutants, which stem from reactions of primary pollutants, when taking production process into account (Unep, 2004) Trees and plants have been labeled as the "lungs of cities" acting as natural filters and reducing air pollution, therefore we can use the ornamental plants as to remediate the air pollution through absorb and degrade all types of urban air pollutants thereby reducing air pollution levels (Brown, 1997; Yoneyama et al., 2002; Burchett, 2008)

Ornamentals and woody trees can use as ecofriendly alternatives for the removal of the pollutants from the air.

\section{Trees as phytoremediators}

Trees are ideal in the remediation of heavy metals as they can withstand and accumulate higher concentration of pollutants owing to their large biomass and size, can reach a huge area and great depths for their extensive rootings and can stabilize an area (Shah and Nongkynrih, 2007)

Fast-growing trees (such as poplar, pine, and eucalyptus) and the hardwood trees, mahogany and rosewood, as well as poplar and eucalyptus, can be used for remediation of contaminated air. The total amount of air pollution removed by urban trees annually within the United States is estimated to be 711,000 metric tons (Nowak et al., 2006)

Concentrations of five metals (cadmium, chromium, copper, nickel and lead) were determined in tree leaves collected from 13 areas of the Attica basin and Athens city, Greece. Geographical distribution patterns were investigated, and factors affecting toxic element accumulation in trees were discussed (Sawidis et al., 2012).

The mean heavy metal content in the tree leaves is described in the descending order of copper $>$ lead $>$ nickel $>$ chromium $>$ cadmium .

Generally, the most damaged areas have been proved to be those near the city center and in the vicinity of the Attica highway. The geomorphological relief of the area plays an important role in the dispersion of airborne particles from pollution sources to the 
surrounding area. Areas on the NE region are also polluted mainly due to wind directions. In Citrus aurantium leaves, with relatively impermeable cuticle, high chromium, copper and nickel concentration would be possibly caused only by significant stomatal uptake. The conifer tree Pinus brutia providing a rough leaf surface also showed elevated concentrations, especially of cadmium and lead. The thick waxy cuticle of the sclerophyllous broad-leaved Olea europaea forms a smooth sheet increasing the barrier properties of the leaf epidermis and causing a reduction in leaf permeability. The dense trichomes of the abaxial epidermis of $O$. europaea also act as a pollution screen keeping away the air particles from the epidermis stomata. The presence of a certain metal within the leaf cells could reduce the uptake or toxicity of some others (Nahed et al., 2015).

\section{Properties of the ornamental plants used as air phytoremedators}

The important criteria for the ornamental plants to be phytoremetioter for air pollution are plants should be evergreen, large leaved, rough bark, indigenous, ecologically compatible, low water requirement, minimum care, high absorption of pollutants, resistant pollutants, agro-climatic suitability, height and spread, Canopy architecture, Growth rate and habit (straight undivided trunk), Aesthetic effect (foliage, conspicuous and attractive flower colour), Pollution tolerance and dust scavenging capacity (Kumar et al., 2013).

A few ways in which plants reduce air pollution are as follows (Brethour et al., 2007):-

Absorption of gaseous pollutants through their leaves, e.g., ozone, nitrogen oxides, and sulphur dioxide.

Further reducing ozone concentrations at ground level by reducing the temperature via evapotranspiration as mentioned above.
Collection of dust, ash, pollen and other particulate matter on their leaves hence reducing its presence in the air breathed.

Releasing of oxygen, as mentioned above, which increases the quality of the air for human use (McPherson 2005).

The amount of air-borne pollutants removed increases with leaf surface area. Therefore, trees tend to be better filters than shrubs and grasses. Due to their large surface area and year round coverage, conifers (evergreens) are very good pollution filters. However, conifers tend to be sensitive to phytotoxic air pollutants and deciduous trees are more efficient at absorbing gaseous pollutants. It is, therefore, beneficial to have a mixture of species in order to have the greatest effect in reducing air pollution (Bolund and Hunhammar 1999).

The phytoremediation properties of some ornamental plants used in landscape have been investigated (Füsun et al., 2011).

Leaf samples of the plant species belong to leafy, coniferous and shrub were taken from the refuge of main road in the campus area affected heavy metal pollution due to intensive motorized traffic, and from the coastal areas far away from the intensive traffic. Nickel, lead, cadmium, iron, zinc and copper concentrations were determined in leaf samples. There were significant differences among the plant species $(\mathrm{P}<0.01)$ according to $\mathrm{Fe}, \mathrm{Zn}, \mathrm{Cu}, \mathrm{Ni}, \mathrm{Pb}$ and $\mathrm{Cd}$ contents of leaves. There were also significant differences among the locations $(\mathrm{P}<0.01)$ for $\mathrm{Fe}, \mathrm{Zn}$, and $\mathrm{Cd}$ contents of leaves. Interactions between locations and plant species were significant $(\mathrm{P}<0.01)$ for the heavy metals, except $\mathrm{Pb}$. The highest $\mathrm{Fe}, \mathrm{Zn}, \mathrm{Cu}$, and $\mathrm{Cd}$ concentrations were obtained in species of Cedrus libani A. Rich (618 ppm), Betula Alba Linn. (106.30 ppm), Salix Alba L. (24.54 ppm) and Eleagnus angustifolia L. (0.28 ppm), 
respectively. The highest $\mathrm{Ni}(6.36 \mathrm{ppm})$ and $\mathrm{Pb}$ (3.76 ppm) contents were determined in Pyracantha coccinea M. Roem (Füsun et al., 2011).

Twenty-eight ornamental species commonly used for interior plantscapes were screened for their ability to remove five volatile indoor pollutants: aromatic hydrocarbons (benzene and toluene), aliphatic hydrocarbon (octane), halogenated hydrocarbon [trichloroethylene (TCE)], and terpene ( $\alpha$-pinene). Of the 28 species tested, Hemigraphis alternata, Hedera helix, Hoya carnosa, and Asparagus densiflorus had the highest removal efficiencies for all pollutants; Tradescantia pallida displayed superior removal efficiency for four of the five VOCs (i.e., benzene, toluene, TCE, and $\alpha$-pinene). The five species ranged in their removal efficiency from 26.08 to $44.04 \mu \mathrm{g} \cdot \mathrm{m}^{-3} \cdot \mathrm{m}^{-2} \cdot \mathrm{h}^{-1}$ of the total VOCs.

Fittonia argyroneura effectively removed benzene, toluene, and TCE. Ficus benjamina effectively removed octane and $\alpha$-pinene, whereas Polyscias fruticosa effectively removed octane. The variation in removal efficiency among species indicates that for maximum improvement of indoor air quality, multiple species are needed. The number and type of plants should be tailored to the type of VOCs present and their rates of emanation at each specific indoor location (Sawidis et al., 2012).

It is better to arrange some species of plants to achieve the best removal effects taking account of concentrations, fumigation time and pollutants (Yang et al., 2009). On five species of streetscape plants were identified as ornamental shrubs i.e. Ixora Red, Yellow Bush, Masquerade Pine, Tuja Pine and Yellow ficus (Enete and Ogbonna 2012). The Air pollution tolerance index (APTI) values ranged between 10.60 and 14.32 on yellows Bush and Ixora Red respectively. The ornamental shrubs with lower APTI values (sensitive) were recommended to be utilized as bioindictors of poor urban air quality while shrubs with high APTI values (Tolerant) are to be planted around areas anticipated having high air pollution load (Enete and Ogbonna 2012). Sixteen ornamental plant species commonly used for interior plantscapes were screened for their ability to remove three common indoor pollutants of formaldehyde, nitrogen oxides (NOx) and sulfur oxides (SOx) (El-Sadek et al., 2012). Also, some components of the selected plants such as, ascorbic acid, chlorophyll, $\mathrm{pH}$, relative water content, leaf osmotic pressure as well as stomatal number, length and width on the lower and upper leaf surfaces were assessed to determine the relationship between these components and plant removal efficiency. Among the tested plants, Chlorophytum comosum displayed superior removal efficiency for HCHO and SOx as $1830 \mu \mathrm{g}$ day $^{-1}$ and $2120 \mu \mathrm{g}$ day $^{-1}$ and Spathiphyllum wallisii for NOx as $3200 \mu \mathrm{g}$ day $^{-1}$. Also, it was found that stomatal density can be used as an indicator for the efficiency of indoor plants in the absorption of air pollutants; especially for $\mathrm{HCHO}, \mathrm{SOx}$ or NOx (Aini et al., 2012).

The responses of plants to pollutants may provide a simple link concerning phytoremediation of air pollutants to admit air pollution abatement. Ten species of landscape plants (Jatropha pandurifolia, Bougainvillea sp., Cordyline terminalis, Canna indica, Hymenocallis speciosa, Mussaenda philippica, Codiaeum variegatum, Heliconia psittacorum, Sansevieria trifasciata and Ipooea batatas) have been identified as ornamental shrubs and herbaceous, and their potential for bioindicators of urban air pollution based on their Air Pollution Tolerance Index (APTI) (Nugrahani et al., 2012). From the literatures, the success of green technology in phytoremediation, in general, is dependent upon several factors (Paz-Alberto and Sigua 2013). Firstly, plants 
must produce sufficient biomass while accumulating high concentrations of metal. In some cases, an increased biomass will lower the total concentration of the metal in the plant tissue, but allows for a larger amount of metal to be accumulated overall. Secondly, the metal-accumulating plants need to be responsive to agricultural practices that allow repeated planting and harvesting of the metalrich tissues. Thus, it is preferable to have the metal ac-cumulated in the shoots as opposed to the roots, for metal in the shoot can be cut from the plant and removed. This is manageable on a small scale, but impractical on a large scale. If the metals are concentrated in the roots, the en-tire plant needs to be removed. Yet, the necessity of full plant removal not only increases the costs of phytoremediation, due to the need for additional labor and plantings, but also increases the time it takes for the new plants to establish themselves in the environment and begin accumulation of metals lists some of the common pollutant accumulating plants found by phytoremediation researchers (PazAlberto and Sigua, 2013). A list of plants which are effective air purifiers along with the pollutants that they are best at removing was provided (Prescod, 1990; Prescod, 1992). He reported that orchids are very effective at removing numerous pollutants during the daylight hours. They are also effective at removing carbon dioxide and xylene18 at night, while at the same time releasing oxygen into the air. This is because orchids (and bromeliads) have a unique metabolic process whereby their stomata 20 open at night. This is significant because air can be continuously filtered, day and night (Prescod, 1992). It is important to acknowledge, however, that plants can also contribute to reduce air quality by releasing pollen and spores 42 which can cause discomfort in the form of allergies (Prescod, 1990).

Fig.1 Installation of vertical gardens on metro pillars in Bengaluru for pollution control

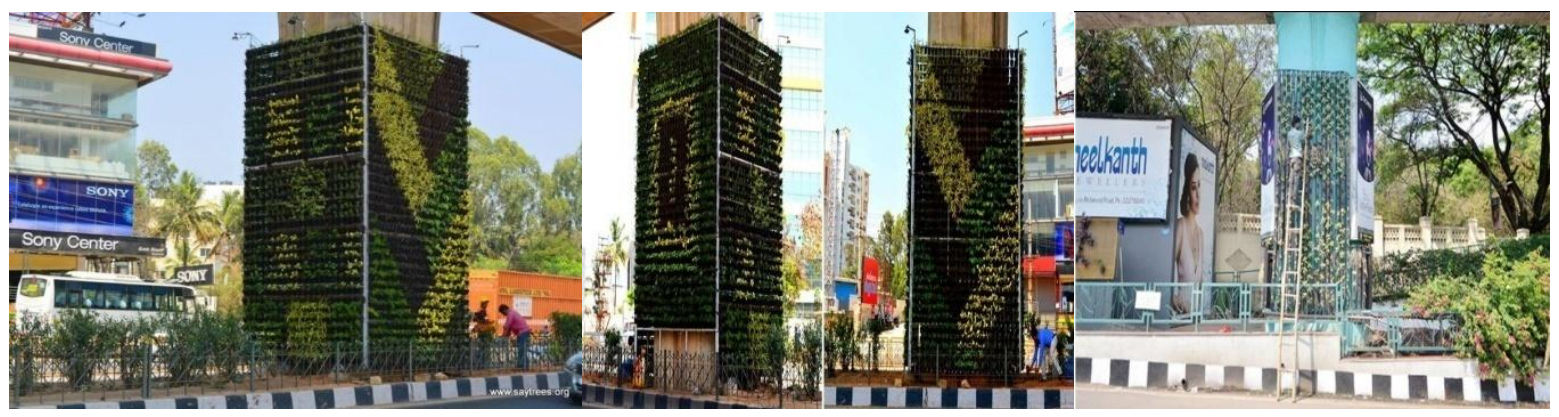

Fig.2 Arrangement of different indoor plants for pollution control

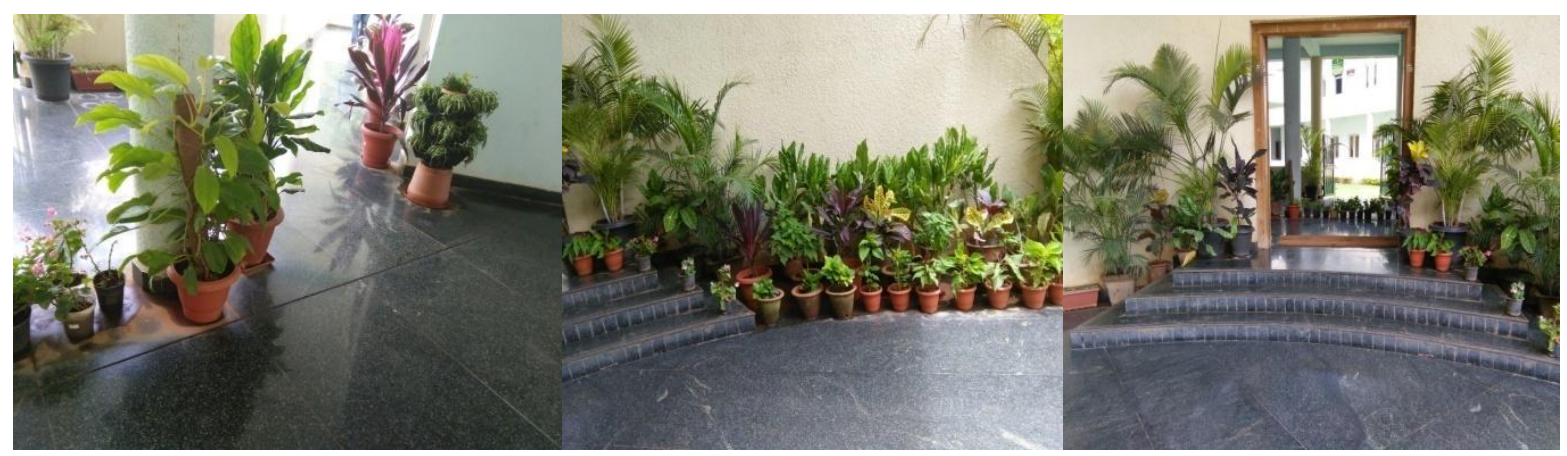


Table.1 Major air pollutants in the environment, pollutant sources and their effect on public health

\begin{tabular}{|c|c|c|}
\hline Outdoor pollutant & Pollutant sources & Health problem \\
\hline Carbon Monoxide & $\begin{array}{l}\text { Burning diesel, petroleum and } \\
\text { wood }\end{array}$ & $\begin{array}{l}\text { Increases confusion, sleepiness, low } \\
\text { blood oxygen level, slow reflexes }\end{array}$ \\
\hline Carbon dioxide & Burning oil, coal and natural gases & $\begin{array}{l}\text { Lowers oxygen levels, vision defects, } \\
\text { reduces respiratory and brain } \\
\text { functions, }\end{array}$ \\
\hline Nitrogen dioxide (NO2) & $\begin{array}{l}\text { Burning fuels, electricity } \\
\text { generation plus vehicle engines, }\end{array}$ & $\begin{array}{l}\text { defect in lung function and causes } \\
\text { bronchitis in asthmatic children, toxic }\end{array}$ \\
\hline Sulphur dioxide (SO2) & $\begin{array}{l}\text { industrial processes, and Burning } \\
\text { fossil fuels }\end{array}$ & $\begin{array}{l}\text { eye irritation and respiratory } \\
\text { inflammation, asthma attacks,, mucus } \\
\text { secretion, decreases pulmonary } \\
\text { function. }\end{array}$ \\
\hline Ozone (O3) & $\begin{array}{l}\text { photochemical smog produced by } \\
\text { the interaction of sunlight and air } \\
\text { pollutants }\end{array}$ & $\begin{array}{l}\text { breathing difficulties and } \\
\text { asthma, colds, pneumonia }\end{array}$ \\
\hline $\begin{array}{l}\text { Suspended particulate } \\
\text { matter (PM10, PM2.5, } \\
\text { SPM) }\end{array}$ & $\begin{array}{l}\text { Mixture of solid and liquid organic } \\
\text { plus inorganic materials including } \\
\text { nitrates, sulphate, carbon, sodium } \\
\text { chloride, ammonia, mineral dust } \\
\text { and water }\end{array}$ & $\begin{array}{l}\text { Disrupts lung's gas exchange function } \\
\text { and respiratory illness }\end{array}$ \\
\hline
\end{tabular}

(Kapoor, 2017)

Table.2 Indoor plants suitable for air pollution control

\begin{tabular}{|l|l|l|}
\hline Name of the plant & Family & Growth habit \\
\hline Dypsis lutescens & Araceae & Erect, small, \\
\hline Dendrobium (orchid) & Orchidaceae & Small plant \\
\hline Dracaena & Liliaceae & Small plant \\
\hline Hedera helix & Araliaceae & Vigorous climber \\
\hline Dieffenbachia & Arecaceae & Small plant \\
\hline Nephrolepis obliterata & Lomariopsidaceae & Small plant \\
\hline Rhapis excelsa & Areceae & Small palm \\
\hline Chlorophytum comosum & Liliaceae & Medium plant \\
\hline $\begin{array}{l}\text { Spathiophyllum } \\
\text { Aloe vera }\end{array}$ & Areceae & Small palm \\
Small plant
\end{tabular}

(Kapoor, 2017, Cristiano et al., 2016, Orwell et al., 2006; Lohr et al., 1994 and Wood et al., 2006)

Table.3 Outdoor plants suitable for air pollution control

\begin{tabular}{|l|l|l|l|}
\hline Name of the plant & Family & Growth habit & $\begin{array}{l}\text { Environmental } \\
\text { importance }\end{array}$ \\
\hline Pongamia Pinnata & Leguminosae & Small tree & Suitable for avenues \\
\hline Pithecellobium dulce & Fabaceae & Large tree & $\begin{array}{l}\text { Suitable for road } \\
\text { planting for road }\end{array}$ \\
\hline Holoptelea integrifolia & Ulmaceae & Large tree & $\begin{array}{l}\text { Suitable for } \\
\text { planting }\end{array}$ \\
\hline
\end{tabular}




\begin{tabular}{|c|c|c|c|}
\hline Saraca indica & Leguminosae & Small tree & Suitable for avenues \\
\hline Sorbus aria & Rosaceae & Medium tree & $\begin{array}{l}\text { Suitable for industrial } \\
\text { area }\end{array}$ \\
\hline Acer campestre & Sapindaceae & Medium tree & $\begin{array}{l}\text { Suitable for industrial } \\
\text { area }\end{array}$ \\
\hline $\begin{array}{l}\text { Pinus nigra var. } \\
\text { maritima }\end{array}$ & Pinaceae & Large tree & Suitable for hilly areas \\
\hline Ficus nitida & Moraceae & Small tree & $\begin{array}{l}\text { High dust capture } \\
\text { capacity }\end{array}$ \\
\hline Eucalyptus globules & Myrtaceae & Large tree & $\begin{array}{l}\text { High dust capture } \\
\text { capacity }\end{array}$ \\
\hline Ficus infectoria & Moraceae & Medium tree & Suitable for avenues \\
\hline Psidium guajava & Myrtaceae & Small tree & Suitable for avenues \\
\hline Ficus rumphii & Moraceae & Large tree & Suitable for road side \\
\hline Azadirachta indica & Meliaceae & Large tree & Suitable for road side \\
\hline Grevillea robusta & Proteaceae & Large tree & Suitable for road side \\
\hline Ficus benghalensis & Moraceae & Large tree & Suitable for road side \\
\hline Ficus religiosa & Moraceae & Large tree & $\begin{array}{l}\text { Suitable for road } \\
\text { planting }\end{array}$ \\
\hline Ziziphus jujuba & Rahmnaceae & Large tree & $\begin{array}{l}\text { Suitable for road } \\
\text { planting }\end{array}$ \\
\hline Phyllanthus emblica & Euphorbiaceae & Large tree & $\begin{array}{lll}\begin{array}{l}\text { Suitable } \\
\text { planting }\end{array} & \text { for } & \text { road } \\
\end{array}$ \\
\hline Cassia fistula & Leguminosae & Medium tree & Suitable for avenues \\
\hline Alstonia scholaris & Apocynaceae & Large tree & Suitable for road side \\
\hline Cassia siamea & Leguminosae & Low growing & Suitable for road side \\
\hline Bauhinia variegata & Leguminosae & Small tree & Suitable for avenues \\
\hline $\begin{array}{l}\text { Caesalpinia } \\
\text { pulcherrima }\end{array}$ & Leguminosae & Large tree & Suitable for road side \\
\hline Delonix regia & Leguminosae & Large tree & Suitable for road side \\
\hline Michelia champaca & Magnoliaceae & Medium tree & $\begin{array}{l}\text { Suitable for industrial } \\
\text { area }\end{array}$ \\
\hline Populus spp. & Salicaceae & Large tree & $\begin{array}{l}\text { Suitable for industrial } \\
\text { area }\end{array}$ \\
\hline Psidium cattleyanum & Myrtaceae & Medium tree & $\begin{array}{l}\text { Suitable for industrial } \\
\text { area }\end{array}$ \\
\hline Tradescantia & Commelinaceae & Small plant & $\begin{array}{l}\text { Suitable for industrial } \\
\text { area }\end{array}$ \\
\hline Petunia & Solanaceae & Small plant & $\begin{array}{l}\text { Suitable for industrial } \\
\text { area }\end{array}$ \\
\hline Madhuca latifolia & Sapotaceae & Small plant & Suitable for avenues \\
\hline $\begin{array}{l}\text { Clerodendron } \\
\text { infortunatum }\end{array}$ & Verbenaceae & Small plant & $\begin{array}{l}\text { Outdoor condition of a } \\
\text { house }\end{array}$ \\
\hline Eupatorium odoratum & Asteraceae & Small plant & Suitable for road side \\
\hline Hyptis suaveolens & Lamiaceae & Small plant & $\begin{array}{l}\text { Outdoor condition of a } \\
\text { house }\end{array}$ \\
\hline Polyalthia longifolia & Annonaceae & Medium tree & Suitable for avenues \\
\hline
\end{tabular}

(Kapoor, 2017; Beckett et al., 2000; Freer-Smith et al., 2004; Rzepka et al., 2005; Pandey, et al., 2005; Lakshmi et al., 2008; Tripathi et al., 2009 and Jyothi and Jaya, 2010) 
However, there is a substantial amount of research that indicates having indoor plants has the net effect of improving indoor air quality (Lohr et al., 1996) (Fig. 2).

\section{Control of indoor air pollution}

Indoor air pollution from solid fuel use and urban outdoor air pollution are estimated to be responsible for 3.1 million premature deaths worldwide every year and $3.2 \%$ of the global burden of disease (WHO, 2009).

More than half of the global burden of disease from air pollution is borne by people in developing countries. Air pollutants have been linked to a range of adverse health effects, including respiratory infections, heart disease and lung cancer. Reduction of air pollution levels will decrease the global health burden related to these illnesses. Efforts to significantly reduce concentrations of air pollutants will also help to decrease greenhouse gas emissions and mitigate the effects of global warming (WHO, 2008). Indoor concentrations of some cancerous chemicals are between 5 and even up to 70 times higher than outdoors, although the indoor concentration of pollutants is still lower than in industrial factories and heating power stations or next to busy roads(Brody, 2001,Wood, 2003 and Gawrońska et al., 2015.)

A number of air pollutants have been recognized to exist indoors, including NOx, $\mathrm{SO} 2, \mathrm{O} 3, \mathrm{CO}$, volatile and semi-volatile organic Compounds (VOCs), PM, radon, and microorganism. Some of these pollutants (e.g., NOx, SO2, O3, and PM) are common to both indoor and outdoor environments, and some of them maybe originated from outdoors (Leung, 2015).

The major sources of indoor air pollution worldwide include indoor combustion of solid fuels, tobacco smoking, outdoor air pollutants, emissions from construction materials and furnishings, and improper maintenance of ventilation and air conditioning systems (WHO, 2010.). While outdoor sources of air pollutants include vehicles, combustion of fossil fuels in stationary sources, such as power generating stations, and a variety of industries. Forest fires and deliberate biomass burning, although intermittent sources of air pollution, represent major sources of combustion pollution globally (WHO, 2010.) Many studies have confirmed that indoor air quality is highly affected by outdoor air quality (Leung, 2015). As our population continues to urbanize, the number of people spending $80-90 \%$ of their time indoors 52 is also increasing (Orwell, 2004). Many studies have reported that the concentrations of volatile organic compounds are higher indoors than outdoors (Sakai et al., 2004).

Plants continue to function as atmospheric filters indoors as they do outdoors and enhance the air quality of confined environments. Recent studies show that indoor plants are effective at removing VOCs (Orwell, 2004). The best indoor plants that could be used to improve indoor air quality in a small office space was studied (Aini et al., 2012). They found that, the concentration of Volatile Oil Compound (VOC) inside a room was monitored before and after the test, using Aeroquol Model S500 VOC Gas Detector and by using oil-based paint painted on a panel measuring $0.05 \times 0.05 \mathrm{~m}$ in order to create a minimum of 3ppm of (VOC) (Aini et al., 2012). Three types of tropicalindoor plants were used in this study; Nephrolepis exaltata, Rhapis excels and Dracaena fragrans. Data were monitored for eight hours at 10 minutes interval. The results showed no significant differences between the number of pots and the type of plants used in reducing VOC content in the real room environment. This was probably due to several factors, such as the interference of outside air and the 
condition of the experimental room. This experiment suggests that further experiments should be carried out in a controlled environment to improve our knowledge of how indoor plants can improve indoor air quality, and thus improve human health and well-being (Aini et al., 2012).

The most important step to reduce exposure to the selected pollutants $\mathrm{HCHO}$, NOx and SOx, is to increase indoor air quality through reducing levels of these pollutants, while at the same time reducing indoor $\mathrm{CO} 2$. The most promising method to achieve this aim is by using suitable indoor plant species (Burchett et al., 2008).

During the 1980's NASA investigated the use of plants as air purifiers. The results of their investigation suggested that one potted plant per 100 square feet of indoor space in an average home or office was sufficient to cleanse the air of pollutants (Nugrahani et al., 2012)

Ten species of ornamental plants that are effective at removing benzene from the air and are, therefore, considered as hyperacumulators at removing other gaseous pollutants were identified (Liu, 2007). The green dragon tree (Dracaena deremensis) was found to be the species with the largest capacity to remove benzene from indoor air. Houses with six or more potted-plants showed reductions of over one third in $\mathrm{NO} 2$ levels (Coward et al., 1996). In another study found that if an office containing $2.5 \mathrm{ppm}$ of each of $\mathrm{B}$ benzene, toluene, xylene and ethylbenzene (TEX) and had an approximate volume of 30 $\mathrm{m} 3$, it contains 16, 8, 22 and $22 \mathrm{mg} / \mathrm{m} 3$ benzene, toluene, xylene and ethylbenzene, respectively. Using ten Opuntia microdasy pots with the same size (10 cm diameter), can remove benzene, toluene, xylene and ethylbenzene totally after 36, 40, 30 and 39 hours(Kim et al., 2011). In the presence of plants, $\mathrm{CO} 2$ levels were reduced by about
$10 \%$ in offices in the air-conditioned building, and by about $25 \%$ in the naturally ventilated building (Tarran et al., 2007). Potted-plants can provide an efficient, self-regulating, lowcost, sustainable, bioremediation system for indoor air pollution, which can effectively complement engineering measures to reduce indoor air pollution, and hence improve human wellbeing and productivity (Wood et $a l .$, 2006). They added that when mean of the total volatile organic compounds (TVOC) loads in the air of reference offices exceeded $100 \mathrm{ppb}$, concentrations were greatly reduced in the presence of any of the three pottedplant (Racaena deremensis) regimes trialled, by from 50-75\% (Wood et al., 2006) (Table 2).

\section{Control of outdoor air pollution}

Outdoor air pollution is believed to cause an estimated 1.3 million annual deaths worldwide, as well as an increased risk of respiratory and cardiovascular diseases (WHO, 2012). Outdoor air pollutants mainly consist of $\mathrm{NOx}, \mathrm{SO} 2, \mathrm{O} 3, \mathrm{CO}, \mathrm{HC}$, and particulate matters (PM) of different particle sizes. In urban areas, these pollutants are mainly emitted from on-road and off- road vehicles, but there are also contributions from power plants, industrial boilers, incinerators, petrochemical plants, aircrafts, ships and soon, depending on the location sand prevailing winds (Leung, 2015,). As with the outdoor environment, particulate matter such as dust, ash, pollen and smoke are also irritants and pollutants of indoor air. The levels of particulate matter accumulation in a room were lower when plants were present than when they were not. In addition to finding a reduction in particulate matter it was also found that relative humidity was slightly higher when plants were present (Prescod,1990). An increase in relative humidity, particularly in heated environments, increases the comfort level. Another means by which indoor plants improve enclosed 
environments is by removing offensive odours from the air (Oyabu et al., 2003) (Table 3).

\section{Advanced technique of air pollution} control

Earlier times, vertical garden (biowalls) are meant for indoor biological air purification which are composed of a variety of plant species and microorganisms that live on their roots (Hum and Lai 2007).

Vertical gardens are a new technology that can add appealing green space, while actively enhancing the air quality in the environment (Curtis and Stuart 2010).

Through microbial activity, airborne contaminants such as volatile organic compounds (VOCs), benzene, toluene and other toxic fumes are degraded into end products that are harmless to humans and the environment.

In addition, biowalls reduce noise pollution, as their plants and planting medium are effective sound barriers. Another benefit of the biowall will be educating those who pass through the building regarding the importance of air quality, and workplace health (Curtis and Stuart 2010).

But now a day, vertical gardens are used to purify the outdoor pollution especially in cosmopolitan cities like Bengaluru, Delhi, Mumbai and Culcatta (Kidiyoor, 2017) (Fig. 1). Biowalls can also effectively improve the environmental conditions by reducing greenhouse gas emissions (Loh, 2000).

\section{Mechanism of air pollution control by ornamental plants}

There are four main ways by which plants reduce air pollution (Kapoor, 2017). These are:

\section{Temperature reduction}

There is a direct relationship exists between the emission of many pollutant and/or ozone forming chemicals with atmospheric temperature. Ozone forming chemicals are also reported to decrease with reduction in air temperature. Plant has a direct effect on temperature, incident radiation, radiation absorption, surface roughness, wind velocity, relative humidity and surface albedo. Trees contribute towards cooler summer temperature. These changes help to create a microclimate in surrounding areas which has the ability to alter the pollutant concentrations in urban and industrial areas (Nowak et al., 1998).

\section{Removal of air pollutant}

The principle process by which plants removed gaseous air pollution is through the stomata, though some gases are also removed by other plant organs. Absorbed gases diffuse into intercellular space react with inner surface of leaves, may be absorbed by water to form acid. Suspended air particle intercepts with the leaf surface, adsorbed on the leaf and dropped to the ground during leaf or twig fall or rain fall (Smith, 1990). It is reported that a large healthy tree $(>77 \mathrm{~cm}$ diameter) remove approximately 70 times more air pollution annually than small healthy trees which having diameter less than $8 \mathrm{~cm}$ (Nowak, 1994).

\section{Emission of Volatile Organic Compounds (VOCs)}

Each and every plant emits certain amount of volatileorganic compounds (VOCs) in the atmosphere. These VOCs are mainly responsible for the formation of ozone and carbon monoxide. However, in the presence of low nitrogen dioxide VOCs actually remove ozone (Crutzen et al., 1985). VOCs emission rates dependent upon the species 
and nine genera have been reported to have very high VOCs emission rate; among them Eucalyptus, Salix, Casuarina are important.

\section{Energy effects on building}

Tress reduces the building energy by lowering temperatures through shading during the summer and blocking winds during winter (Heisler, 1986); however, shading effect may lead to increase energy use during winter while during summer energy use may increase or decrease in the buildings situated near the sea shore. Therefore, proper knowledge of tree placement near the vicinity of the buildings is required to achieve maximum benefit.

As we consider the current scenario of the air pollution in the world, there is a growing need for planting ornamental plants which have the maximum capacity to reduce air pollution. Inclusion of the ornamental plants having pollution mitigating ability in the landscape plan will serve the dual purpose of making the cities green and pollution free in the long run. And a technique like vertical garden (biowalls) helps in reducing the pollution in big cities where the space is big lacuna. By growing more and more ornamental plants we can keep our environment healthy as well as recreational.

\section{References}

Aini Jasmin, G., Noorizan, M., Suhardi, M., AMurad, G. and Ina, K., The use of plants to improve indoor air quality in small office space. Soc. Sci. \& Hum., 2012, 20(2) 493-503

Anonymous.1981. A Guide to Tree Planting. Parks and Recreation Department, Ministry of National Development, Singapore

Barfield, B. J., R. L. Blevins, A. W. Flofle, C. E. Madison, S. Inamder, D. I. Carey, and V. P. Evangelou. 1992. Water quality impacts of natural riparian grasses: Empirical studies. St. Joseph, MI: American Society of Agricultural Engineers. ASAE Paper No. 22100

Beckett, K.P.; Smith, P.F. and Taylor, G. 2000. Effective tree species for local air quality management. Journal of Arboriculture, 26(1): 12-18.

Bolund, P. and Hunhammar, S., Ecosystem Services in Urban Areas. Ecological Economics, 1999,29:293-301.)

Brethour, C., Watson, G., Sparling, B., Bucknell, D. and Moore, T., 2007. Literature Review of Documented Health and Environmental Benefits Derived from Ornamental Horticulture Products. Final Report.Geo rge Morris Centre, http://www.deenenla ndscaping.com/UserFiles/file/Morris_R eport.pdf.

Gawrońska, H. and Bakera, B. 2015. Phytoremediation of particulate matter from indoor air by Chlorophytum comosum L. Plants. Air Qual Atmos Health, 8:265-272.

Brown, S.K. 1997. Volatile organic compounds in indoor air: sources and control, Chemistry in Australia, 64(Jan/Feb), 10-13.

Burchett, M., Torpy, F. and Tarran, J. 2008. Interior plants for sustainable facility ecology and workplace productivity. Proc. of Ideaction'08-Enabling Sustainable Communities; Gold Coast, Qld.

Chakre, O. J. 1984. Atmospheric pollens: The organic pollutants. Science Service, 3(8): 4.

Chee, T. Y. and Ridwan, S. 1984.Fastgrowing species of trees suitable for urban roadside and shade planting. Malaysian Forum, 47: 263-284.

Chhotu, D.J. and Fulekar, M.H. 2009. Phytoremediation of heavy metals: 
Recent techniques. African J. Biotech., 8(6):921-928.

Coward, M., Ross, D., Coward, S. 1996. "Pilot Study to Assess the Impact of Green Plants on NO2 Levels in Homes", Building Research Establishment Note N154/96, Watford, UK.

Cristiano, G., Murillo-Amador, B., andDe Lucia, B. 2016. Propagation Techniques and Agronomic Requirements for the Cultivation of Barbados Aloe (Aloe vera (L.) Burm. F.) - A Review. Frontiers in Plant Science, 7.

Crutzen, P.J.; Delany, A.C.; Greenberg, J.; Haageson, P.; Heidt, L.; Lueb, R.; Pollok, W.; Seiler, W.; Wartburg, A. and Zimmerman, P. 1985. Tropospheric chemical composition measurements in Brazil during the dry season. Journal of Atmospheric Chemistry, 2: 233-256.

Curtis, L. and Stuart, M. 2010. Enhancing CHBE Indoor Air Quality: Biowall Technology, Improving air quality in CHBE through a biowall - feasibility study, University of British Columbia CHBE 485.

Dochinger, L. S. 1973. Miscellaneous Publication No.1230.USDA, Forest Service, Upper Darby, Pa, pp. 22.

El-Sadek, M., Koriesh, E., Fujii, E., Moghazy, E. and Abd Elfatah, Y. 2012. Correlation between some components of interior plants and their efficiency to reduce formaldehyde, nitrogen and sulfur oxides from indoor air. Int. Res. J. Plant Sci., 3(10) 222-229.

Enete, I.C. and Ogbonna, C.E. 2012, Evaluation of Air Pollution Tolerance Index (APTI) of some Selected Ornamental Shrubs in Enugu City, Nigeria. J. Enviro. Sci. Toxicol. And Food Techn, 1(2) 22-25.

Freer-Smith, P.H.; El-Khatib A.A. and Taylor, G. 2004. Capture of particulate pollution by trees: a comparison of species typical of semi-arid areas (Ficus nitida and Eucalyptus globulus) with European and North American species. Water, Air, and Soil Pollution, 155: 173-187.

Füsun, G., Çig, A. and Sönmaz, F. 2011. The Determination of Phytoremediation Levels of Ornamental Plants Used in Landscape. J. Int. Environ. Application \& Sci., 6 (5):661-667.

Gawrońska, H. and Bakera, B. 2015. Phytoremediation of particulate matter from indoor air by Chlorophytum comosum L. Plants. Air Qual. Atmos Health, 8:265-272.

Heiser, G.M. 1986. Energy savings with trees. Journal of Arboriculture, 12(5): 113 125.

Hum, R. and Lai, P. 2007. Assessment of Biowalls: An Overview of Plant- and Microbial based Indoor Air Purification System. http://www.queensu.ca/sustain ability/sites/webpublish.queensu.ca.sus www /files/files/biowalls.pdf

Ingold, C. T. 1971. Fungal Spores. Clarendon Press, Oxford

Jyothi, S.J. and Jaya, D.S. 2010. Evaluation of air pollution tolerance index of selected plant species along roadsides in Thiruvananthapuram, Kerala. Journal of Environmental Biology, 31: 379-386.

Kapoor Manish, 2017, Managing Ambient Air Quality Using Ornamental PlantsAn Alternative Approach Universal Journal of Plant Science 5(1): 1-9.

Kidiyoor Suchith, 2017. Metro pillars a vertical garden, Bangalore Mirror Bureau, March 10, pp 2.

Kim, K.J., Yoo, E.H., Jeong, M., Song, J.S. and Lee, S.Y. 2011. Changes in the Phytoremediation Potential of Indoor Plants with Exposure to Toluene., Hort Sci., 46 (12) 1646-1649.

Klassen, S.P, McLean, J.E. Grossel, P.R. and Sims, R.C. 2000. Fate and behavior of 
lead in soils planted with metalresistant species (River birch and small wing sedge). J. Environ. Qual., 29: 1826-1834.

Kumar, R.S., Arumugam, T., Anandakumar, C.R., Balakrishnan, S. and Rajavel, D.S. 2013. Use of Plant Species in Controlling Environmental Pollution-A Review. Bull. Env. Pharmacol. Life Sci., 2 (2):52-63.

Lakshmi, P. S., Sravanti, K.L. and Srinivas N. 2008. Air pollution tolerance index of various plant species growing in industrial areas. The Ecoscan, 2(2): 203-206.

Leung, D.Y.C., 2015. Outdoor-indoor air pollution in urban environment: challenges and opportunity. Front. Environ. Sci., 2(69):7.

Liu, Y.J., Mu, Y., Zhu, Y., Ding, H. and Arenset, N.C.2007. Which ornamental plant species effectively remove benzene from indoor Air? Atmospheric Environ, 41 (3): 650-654.

Loh, S., 2000. Living Walls - A Way to Green the Building Environment. BEDP Environment Design Guide.TEC 26.

Lohr, V.L.; Goodwin, G.K. and PearsonMims, C.H. 1994. Effect of interior plants on relative humidity and air borne particulate matter in indoor environment. Hort Science, 29: 504.

Lohr, V.I., Pearson-Mims, C.H. and Goodwin, G.K., 1996. Interior plants may improve worker productivity and reduce stress in a windowless environment. J. of Environmental Horticulture 14(2):97-100.

Maheshwari, J. K., 1963. The Flora of Delhi. Council of Scientific and Industrial Research, New Delhi.

McPherson, E. G. 2005. Trees with Benefits. American Nurseryman April 1: 34-40.

Nahed, G.A.E., Mona, H. M., Azza, Mazhar, M. M., Farahat, M. M. and Hussein, F.
A. 2015. Potentiality of Ornamental Plants and Woody Trees as Phytoremidators of Pollutants in the Air: A Review. Int.J. ChemTech Res., 8(6):468-482.

Nowak, D.J. 1994. Air pollution removal by Chicago's urban forest. In: McPherson, E.G., D.J. Nowak and R.A. Rowntee. Chicago's urban Forest Ecosystem: Results of the Chicago Urban Forest Climate Project. USDA Forest Service General Technical Report NE-186. pp. 63-81.

Nowak, D.J., Craneand, D.E. and Stevens, J.C. 2006. Air Pollution Removal by Urban Trees and Shrubs in the United States. Urban Forestry \& Urban Greening, 4: 115-123.

Nowak, D.J., McHale, P.J., Ibarra, M., Crane, D., Stevens, J., and Luley, C. 1998. Modeling the effects of urban vegetation on air pollution, In: Air Pollution Modeling and Its Application XII. (S. Gryning amd N. Chaumerliac, eds.) Plenum Press, New York, pp. 399-407.

Nugrahani, P., Prasetyawati, E.T., Sugijanto and Purnobasuki, H. 2012. Ornamental shrubs as plant palettes elements and bioindicators based on air pollution tolerance index in Surabaya city, Indonesia. Asian J. Exp. Biol. Sci., 3 (2): 298-302.

Oommanchan, M. 1977. The Flora of Bhopal (Angiosperms). J. K. Jain Brothers, Bhopal.

Orwell, R.L., Wood, R.L., Tarran, J., Torpy, F. and Burchett, M.D. 2004. Removal of benzene by the indoor plant/substrate microcosm and implications for air quality. Water, Air and Soil Pollution, 157: 193-207.

Orwell, R.L.; Wood, R.A.; Burchett, M.D.; Tarran, J. and Torpy, F. 2006. The potted plant microcosm substantially reduces indoor air VOC pollution: II. 
Laboratory study. Water, Air and Soil Pollution, 177: 59-80.

Oyabu, T., Sawada, A., Vitae, A., Onodera, T., Vitae, A., Takenaka, K., Vitae, A. and Wolverton, B. 2003. Characteristics of potted plants for removing offensive odors. Sensors and Actuators, 89: 131136.

Pandey, S.K., Sharma, A.P, Prajapati, S.K. and Tripathi, B.D. 2005. Screening of heavy metals in the ambient air of a subtropical industrial area, using leaves of Ficus infectoria: A keystone species. In Books of Abstracts, Third International Conference on Plant and Environmental Pollution, 29th Nov.-2, Dec., NBRI, Lucknow, India. p. 9 SI/P23.

Paz-Alberto, A.M. and Sigua, G.C., 2013. Phytoremediation: A Green technology to remove environmental pollutant. Am. J. Climate Change, 2: 71-86.

Pokhriyal, T.C. and Subba Rao, B. K., 1986. Role of forests in mitigating air pollution. Indian For. 112: 573-582.

Powe, N. A. and K. G. Willis. 2004. Mortality and Morbidity Benefits of Air Pollution (SO2 and PM10) Absorption Attributable to Woodland in Britain. Journal of Environmental Management 70 (2): 119-128.

Prescod, A.W., 1990. Growing indoor plants as air purifiers. Pappus, 9 (4): 13-20.

Prescod, A.W., 1992. More indoor plants as air purifiers. Pappus, 11 (4) 17-24.

Rzepka, M.A., Cuny1, D., Davranche, L., Cazier, F., Denayer, F.O. and Haluwyn, C.V., 2005. Air quality assessment in an industrial area in France using monitoring plants. In Books of Abstracts, Third International Conference on Plant and Environmental Pollution, 29th Nov.-2, Dec., NBRI, Lucknow, India. p. 9 SI/O17.
Sakai, K., Norbäck, D., Mi, Y., Shibata, E., Kamijima, M., Yamada, T. and Takeuchi, Y., 2004. A Comparison of indoor air pollutants in Japan and Sweden: formaldehyde, nitrogen dioxide, and chlorinated volatile organic compounds. Environ. Res., 94:75-85.

Sawidis, T., Krystallidis, P., Veros, D. and Chettri, M., 2012. A study of air pollution with heavy metals in Athens city and Attica basin using evergreen trees as biological indicators., Biol. Trace Elem. Res., 148 (3) 396-408.

Shah, K. and Nongkynrih, J.M., 2007. Metal hyper accumulation and bioremediation: Review. Biologia Plantarum, 51 (4): 618-634

Shetye, R. P. and Chaphekar, S. B., 1989. Some estimation on dust fall in the city of Bombay, using plants. In: Progress in Ecology, 4:61-70.

Sharma, P.D.2014. Ecology and Environment. Rastogi publication, Capital offeset press, New Delhi, India. 255-319.

Singh, V., 2013. Role of medicinal Plant in controlling environmental (Air) pollution. Internatl. Ayur. Med. Jour. $1(5)$.

Smith, W.H. 1990. Air pollution and forests. New York. Springer-Verlag. 618p.

Tarran, J., Torpy, F. and Burchett, M., 2007. Use of living pot-plants to cleanse indoor air - Research Review., Proceedings of Sixth International Conference on Indoor Air Quality, Ventilation \& Energy Conservation in Buildings - Sustainable Built Environment, Sendai, Japan, Vol. III, 249-256.

Tripathi, A.; Tiwari, P.B.; Mahima and Singh, D. 2009. Assessment of air pollution tolerance index of some trees in Moradabad city, India. Journal of Environmental Biology, 30(4): 545-550. 
Unep, M., 2004. Declaration on Control and Prevention of Air Pollution and its likely Transboundary Effects for South Asia., pp. 9-16.

WHO, 2009. Global health risks: Mortality and burden of diseases attributable to selected major risks. Geneva, World Health

Organization, http://www.who.int/healt hinfo /global_burden_disease/GlobalHealthRi sks_report_full.pdf.

WHO, 2008. Air quality and health. Geneva, World Health Organization (WHO Fact Sheet No. 313, http://www.who.int/mediacentre/factsh eets/fs313/en/index.html.

WHO, 2010. Preventing disease through healthy environments exposure to air pollution: A major public health concern,

http://www.who.int/ipcs/features/air_po llution.pdf

WHO, 2012. Public Health and Environment (PHE): Health Impacts-Are There Health Effects from Both Short and Long Term Exposure to Urban Outdoor Air Pollution. Geneva, Switzerland: World Health Or ganization. http://www.who.int/phe/hea lth_topics/outdoorair/databases/health_i mpacts/en/index 2. html.

Wood, R.A., Burchett, M.D., Orwell, R.L., Alquezar, R. and torpy, F. 2006. The potted-plant microcosm substantially reduces indoor air VOCs pollution: I.
Office field study. Water, Air and Soil Pollution, 175: 163-180.

Wood, R.A., 2003. Improving the indoor environment for health, wellbeing and productivity. Greening Cities: a new urban ecology, 30 IV. Australian Technology Park, Sydney.

Yang, D.S., Pennisi, S.V., Son, K.C., and Kays, S.J., 2009. Screening indoor plants for volatile organic pollutant removal efficiency. HortSci., 44: 13771381.

Yang, H. and Liu, Y., 2011. Phytoremediation on Air Pollution, The Impact of Air Pollution on Health, Economy, Environment and Agricultural Sources, Dr. M. Khallaf (Ed.), http://www.intechopen.com/book s/the-impact-of-air-pollution-on-health economy environment andagricultural-sources/phytoremediationon-air-pollution).

Yoneyama, T., Kim, H.Y., Morikawa, H. and Srivastava, H.S., 2002. Metabolism and detoxification of nitrogen dioxide and ammonia in plants, In, K. Omasa et al., (eds) Air Pollution and Plant Biotechnology - Prospects for Phytomonitoring and Phytoremediation, Springer, Tokyo, Japan, 221-234.

Zhai, G., 2011. Phytoremediation: Right Plants for Right Pollutants. J. Bioremed Biodegrade, 2:3. http://dx.doi.org/10.4172/21556199.1000102e.

\section{How to cite this article:}

Reshma, V.S., Prashant Kumar and Chaitra, G.S. 2017. Significant Role of Ornamental Plants as Air Purifiers - A Review. Int.J.Curr.Microbiol.App.Sci. 6(8): 2591-2606.

doi: https://doi.org/10.20546/ijcmas.2017.608.308 